\begin{tabular}{|c|c|c|}
\hline \multicolumn{2}{|c|}{ Jurnal Penelitian Pendidikan IPA (JPPIPA) } & (2) \\
\hline \multicolumn{3}{|c|}{$\begin{array}{l}\text { Jurnal Penelitian Pendid1kan IPA (JPPIPA) } \\
\text { P-ISSN : } 2460-2582 \text { |E-ISSN : } 2407-795 \mathrm{X}\end{array}$} \\
\hline Sekretariat & $\begin{array}{l}\text { : Lt. } 3 \text { Gedung Pascasarjana Universitas Mataram } \\
.(0370) 634918\end{array}$ & \\
\hline & nram.ac.id & \\
\hline Website & : http://jppipa.unram.ac.id/index.php/jppipa/index & \\
\hline
\end{tabular}

\title{
RELATIONSHIP BETWEEN THE CLAY COMPOSITION AND THE SOIL SOURCE IN WEST SUMATERA
}

\section{AIDHIA RAHMI ${ }^{\mathbf{1}}$, HELENDRA ${ }^{\mathbf{1}}$}

${ }^{1}$ Pendidikan Fisika, STKIP PGRI Sumatera Barat, Indonesia, Email: aidhia@stkip-pgri-sumbar.ac.id

Accepted: September $22^{\text {st }}, 2018$. Approved: October $10^{\text {st }}, 2018$. Published: November $27^{\text {st }}, 2018$ DOI: $10.29303 /$ jppipa.v5i1.152

\begin{tabular}{|c|c|}
\hline Key Words & Abstract \\
\hline $\begin{array}{l}\text { clay mineral, } \\
X R D, X R F, \\
\text { kaolinite, illite- } \\
\text { smectite }\end{array}$ & $\begin{array}{l}\text { Clay mineral is widely used in ceramic materials, building materials, paper coating } \\
\text { materials, catalyst support, and an alternative material for zeolite. This paper } \\
\text { reports the study on the relationship between the position of soil (low and highland) } \\
\text { and its mineral composition in Bukit Tinggi, West Sumatera, Indonesia. It was found } \\
\text { that the lowland area indicates the existence of dominant kaolinite and mikasaite. } \\
\text { Meanwhile the highland is characterized with dominant illite and kaolinite.Illite is } \\
\text { the main component for ceramic. This due to the alkaline condition and high content } \\
\text { of Al and K as well as high hydrothermal activity at high land presumably by } \\
\text { volcanic activity. }\end{array}$ \\
\hline
\end{tabular}

\section{INTRODUCTION}

Clay minerals are the characteristic of soil at the near surface of earth (Hazenet all, 2013). It also play key component in the pottery and ceramic industry. Illite is one of the important clay phase that is highly demanded for high glass phase, high melting point and low water absorption ceramic. Ceramic with high illite content may produce higher percentage of glass phase which leads to better quality product.

Based on their structures and chemical compositions, the clay minerals can be divided into three main classes: kaolinites; smectites and illites (Mukasa-Tebandeke, 2015). The differences in clay structure arise from the way silica tetrahedra and alumina tetrahedral (Madejova, 2013). The kaolinite has a single tetrahedral silica sheet and single octahedral alumina sheet, a combination which repeats itself indefinitely. The crystal structure consists of unit layers, which are stack on one another and held together finally by hydrogen bonding among the hydroxide ions of the octahedral sheet of one layer and the oxygen of the tetrahedral sheet of the adjacent layer. Smectitization occurred only when Feoxidation was considerable. The alteration of smectite was mainly driven by the high alkaline $\mathrm{pH}$-value resulting from $\mathrm{Fe}$-corrosion $(\mathrm{H}$. K Herbert et al, 2016). Chemical denudation and chemical weathering rates vary under climatic, bedrock, biotic, and topographic conditions. Constraints for landscape evolution models must consider changes in these factors on human and geologic time scales (J. C. Austin et al, 2017)

In the field of geology clay is a size-based term for very fine-grained mineralswith an estimated spherical diameter $<2.0 \mu \mathrm{m}$ (Haque, 2013). Differences inthe levels ofcontent of Aland Siin theclay every location caused bygeological structure and mineralization processes in each region contained primarily in the high lands and low lands. In the soils, the various physical processes and chemical reactions lead to the formation of different clay minerals which depend on the nature of the 
reactants and $\mathrm{pH}$ of the weathering environment

In the soils, the various physical processes and chemical reactions lead to the formation of different clay minerals which depend on the nature of the reactants and $\mathrm{pH}$ of the weathering environment. Therefore the physic elementalmineralogical properties of clay do not only determine the clay samples characteristics, but also influences the physical characteristics such as colour and plasticity. Depending on the environmental conditions, some of the primary minerals, such as feldspar, mica, hornblende and quartz may transform themselves into clay minerals (Hossain, 1997). Formation of these clay minerals normally are sticky when wet and shrinks when dry. The objective of the present work was to investigate the relationships between clay source and the illite content in Agam plateau location (Bukit Barisan) and low land location (Salo). The phase of clay minerals, was characterize using X-Ray Diffraction (XRD) supported by elemental composition study using $X$-Ray Fluorescence $(X R F)$.

\section{EXPERIMENT}

Clay materials used in this study were collected from West Sumatera (Figure 1). The particulate matter has been under taken in Agam plateau area (Bukit Barisan) and lowland area (Salo) in West Sumatera. The samples were collected at depths in range of $100 \mathrm{~cm}$ from the surface to avoid the effect of weather condition and contaminant. In the laboratory, visible foreign matters and coarse sand particles were removed manually. The samples were dried at $60{ }^{\circ} \mathrm{C}$ for $24 \mathrm{~h}$. The samples were then crushed using agate mortar to make powder form and then sieved $(250 \mu \mathrm{m}$ sieve $)$ to remove finer sand particles (Ahmadet all, 2009). The fine samples were turned into slurries by mixing adequate amount of distilled water and leaved to settle for 24 hours. Sand particles being relative denser were separated out in the lower portion of the settled slurries, leaving clay sample for study at the top porti

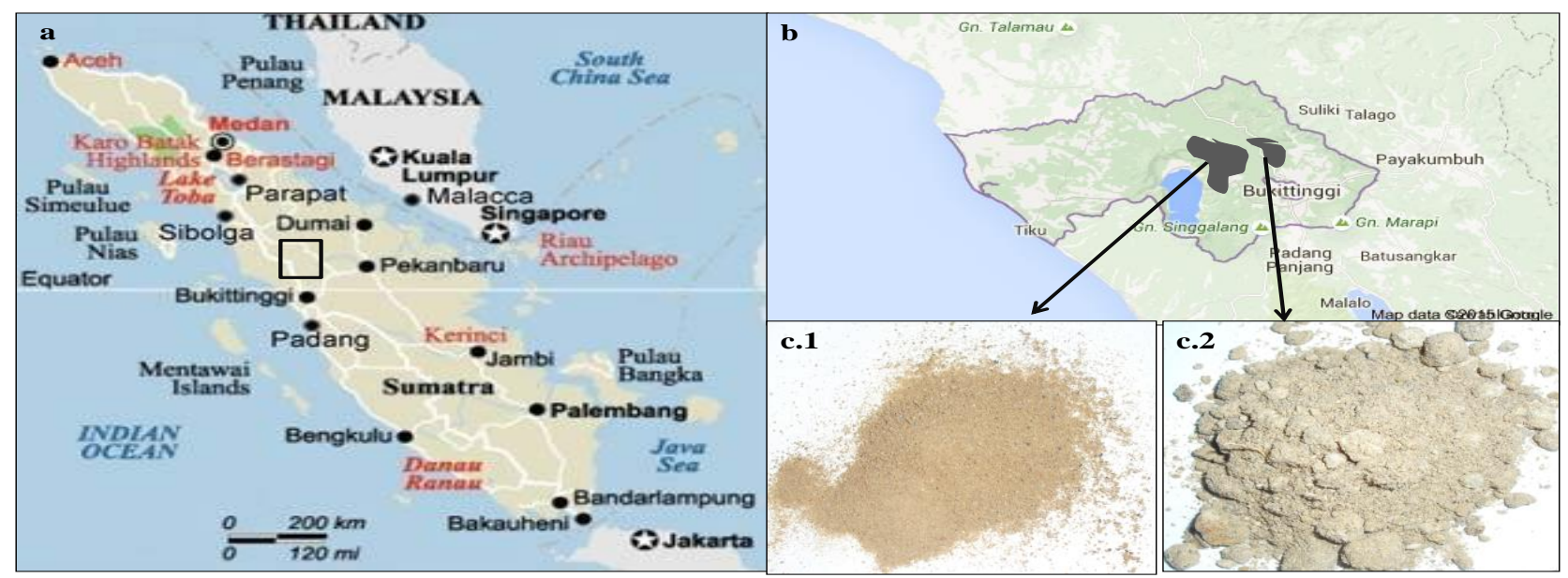

Figure 1. a. Generalized geological map of the Sumatera, Indonesia b. Geographical map showing the location of the study areas c. Soil clay from (1) Agamplateu area (Bukit Barisan) and (2) lowland area (Salo)

In some selected samples, the XRD analysis has been done in the physics laboratory at Padang State University for the identification and estimation of clay minerals. Characterization XRD were taken using tipe X'Pert PRO PW30/40 from PANalytical withCuK $\alpha$ radiation $(\lambda=1.78897 \AA)$. To identify the peaks of different phases, the X'Pert high score plus software installed with ICDD database was used. Manually, it is a tough task to identify all the peaks in XRD pattern of a complex material like soil. The software compares each diffraction pattern in the reference pattern data-base.While, XRF analysis in the chemistry laboratory, Padang State University. The clay was subjected to $\mathrm{XRF}$ to analyse the chemical composition or elements present in the sampleusingPANalytical Epsilon 3. Particle sizes of both samples were determined by particle size analyzer technique (Malvern Zetasizer), with absolute ethanol as its solvent. 
The characterization was performed in Centre for Innovation, Research and Management Laboratory, UniversitiKebangsaan Malaysia, Malaysia.

\section{RESULTS AND DISCUSSION}

Figure. 2 shows typical XRD spectrum for the soil obtained from two different sources namely Agam Plateau (highland) and Salo (lowland) area. It can be seen from the spectrum that the soil from highland contained minerals such as $\mathrm{Al}_{2} \mathrm{H}_{2} \mathrm{~K}_{0.7} \mathrm{O}_{12} \mathrm{Si}_{4}$ (illite), $\mathrm{Al}_{2} \mathrm{Si}_{2} \mathrm{O}_{5}(\mathrm{OH})_{4}$ (kaolinite), illite-smectite and $\mathrm{SiO}_{2}$ (quartz). This material exhibits crystalline phase of monoclinic, anorthic and hexagonal $\beta$ quartz.

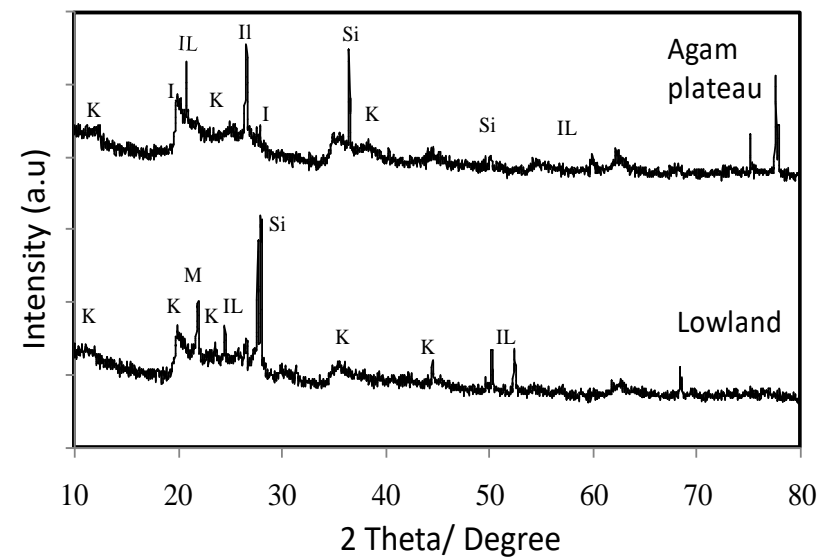

Figure. 2. XRD pattern of clay sediments selected from Agamplateu area (Bukit Barisan) and lowland area (Salo) $(\mathrm{I}=$ illiteK $=$ kaolinite, $\mathrm{IL}=$ illite-smectite, $\mathrm{Si}=$ quartzand $\mathrm{M}=$ mikasaite)

Figure 2 shows typical XRD spectrum for the soil obtained from two different sources namely Agam Plateau (highland) and Salo (lowland) area. It can be seen from the spectrum that the soil from highland contained minerals such as illite $\left(\mathrm{Al}_{2} \mathrm{H}_{2} \mathrm{~K}_{0.7} \mathrm{O}_{12} \mathrm{Si}_{4}\right)$, kaolinite $\left(\mathrm{Al}_{2} \mathrm{Si}_{2} \mathrm{O}_{5}(\mathrm{OH})_{4}\right)$, illite-smectite and $\mathrm{SiO}_{2}$ (quartz). This material exhibits crystalline phase of monoclinic, anorthic and hexagonal $\beta$ quartz. As can be seen from figure 2 or table 1 , the diffraction peaks at $2 \theta$ of $20.02,35.02$, 29.16 and $24.29^{\circ}$ are belongs to $\mathrm{Al}_{2} \mathrm{H}_{2} \mathrm{~K}_{0.7} \mathrm{O}_{12} \mathrm{Si}_{4}$. The peaks at $12.34,24.84$, 38.39 and $39.22^{\circ}$ are for $\mathrm{Al}_{2} \mathrm{Si}_{2} \mathrm{O}_{5}(\mathrm{OH})_{4}$. (Meanwhile the diffraction peaks for illitesmectite are at $2 \theta$ of $24.39,19.74$ and $34.96^{\circ}$. It can be clearly observed that the peaks of $\mathrm{SiO}_{2}$ overlap with the peaks of other minerals in sample and so the other phases are not evidently discernible. The diffraction peak intensities of illite-smectite are very strong; their indicating contents are very high. Illite provides favorable properties to the clays for ceramic use (Carretero et all, 2002). It was reported that in many soils illite or mixed layer illite-smectite is the main clay mineral: especially in young soils of desert regions with strong wet-dry seasonality (Robinson, 1987).

Table 1. List of XRD characterization

\begin{tabular}{|c|c|c|c|c|}
\hline Sample & Mineral & hkl & $2 \theta$ & Lattice constant \\
\hline \multirow[t]{15}{*}{ Agam plateau } & \multirow[t]{4}{*}{ Illite } & [110] & 20.02 & 4.43 \\
\hline & & {$[-131]$} & 35.02 & 2.56 \\
\hline & & [112] & 29.16 & 3.06 \\
\hline & & {$[-112]$} & 24.29 & 3.66 \\
\hline & \multirow[t]{4}{*}{ Kaolinite } & [002] & 24.84 & 3.58 \\
\hline & & [001] & 12.34 & 7.16 \\
\hline & & {$[-202]$} & 38.39 & 2.34 \\
\hline & & [131] & 39.22 & 2.29 \\
\hline & \multirow[t]{3}{*}{ illite-smectite } & {$[-112]$} & 24.39 & 3.64 \\
\hline & & [020] & 19.74 & 4.49 \\
\hline & & {$[-131]$} & 34.96 & 2.56 \\
\hline & \multirow[t]{4}{*}{ Kaolinite } & [002] & 24.78 & 3.59 \\
\hline & & {$[1-32]$} & 45.55 & 1.99 \\
\hline & & [001] & 12.28 & 7.20 \\
\hline & & {$[020]$} & 19.93 & 4.45 \\
\hline \multirow{7}{*}{$\begin{array}{l}\text { Lowland } \\
\text { (Salo) }\end{array}$} & \multirow{3}{*}{ Mikasaite } & [113] & 24.71 & 3.59 \\
\hline & & [104] & 20.25 & 4.38 \\
\hline & & [012] & 14.72 & 6.01 \\
\hline & \multirow[t]{4}{*}{ illite-smectite } & [001] & 10.00 & 8.85 \\
\hline & & [020] & 19.74 & 4.49 \\
\hline & & {$[-112]$} & 24.39 & 3.64 \\
\hline & & [112] & 29.11 & 3.06 \\
\hline
\end{tabular}


The kaolinite clays are common soil minerals which often occur in atmospheric particulate matter, electrostatically neutral and have triclinic symmetry (Kumar and P. Rajkumar, 2014). The higher amount of illite and illite-smectite will increase the liquid limit in the soil, whereas higher amount of kaolinite would decreases the liquid limit in the clay samples, the increase of kaolinite and illitesmectite in the soil decreases coefficient of consolidation. Illite and smectite both consist of alumina-silicate layers alternating with interlayers. In illite the charge of nonexchangeable interlayer cations is balanced by a greater net negative charge on the layers due largely to the substitution of $\mathrm{Al}$ for $\mathrm{Si}$ in the tetrahedral sheets [13Meanwhile, lowland area also contained the same minerals but no illite. However new minerals is found namely mikasite $\left(\mathrm{Fe}_{2} \mathrm{O}_{12} \mathrm{~S}_{3}\right)$ which are presented by the peaks at $2 \theta$ of $3.59 \AA, 4,38 \AA$ and $6.01 \AA$. The difference in clay mineral composition could be due to the depth and temperature properties (Battaglia et all, 2007).

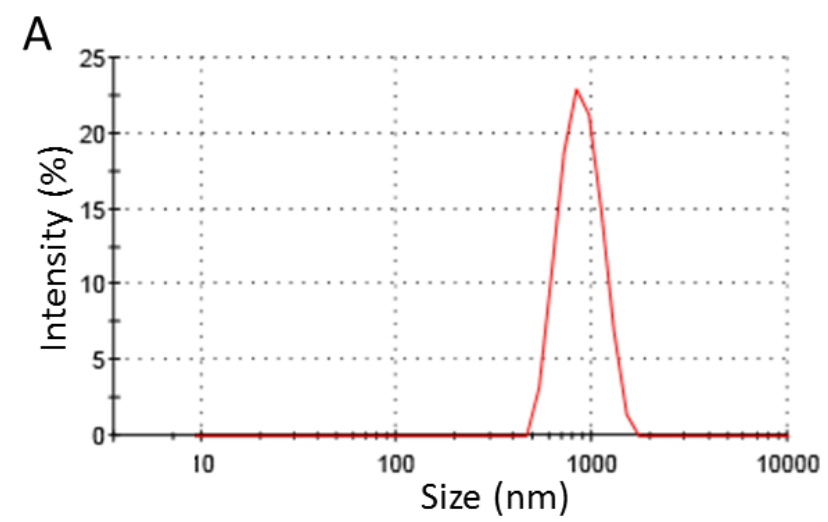

Fig. 3 Particle size distribution fo

Particle sizes of both soils obtain from lowland area and Agam plateau were characterized using particle size analyzer as shown in figure 3. From particle size distribution, the average particle size for lowland area was found to be around $0.88 \mu \mathrm{m}$ while for Agam plateau was around $1.65 \mu \mathrm{m}$ almost twice bigger than the lowland area. From the particle size distribution obtained, it can be conclude that the Agam plateau sample is more uniform in size compared to the sample from lowland area. Even though the size is particularly very big for potential applications,
Table 2.Percentage of element characterized by XRF technique.

\begin{tabular}{lll}
\hline Element & $\begin{array}{l}\text { Agam plateau } \\
\text { conc. }(\%)\end{array}$ & $\begin{array}{l}\text { Lowland (Salo } \\
\text { Area) conc. }(\%)\end{array}$ \\
\hline $\mathrm{Al}$ & 30.27 & 30.618 \\
$\mathrm{Si}$ & 57.382 & 57.482 \\
$\mathrm{Fe}$ & 5.887 & 5.804 \\
$\mathrm{Ca}$ & 2.717 & 2.475 \\
$\mathrm{Ti}$ & 1.247 & 1.247 \\
$\mathrm{~K}$ & 1 & 0.933 \\
\hline
\end{tabular}

We carried out X-Ray Fluorescence (XRF) to determine the elemental composition exists in the caly minerals. The results are shown in Table 2. As can be seen from table 1, there are at least six elements characterized the samples from highland and lowland namely $\mathrm{Al}, \mathrm{Si}, \mathrm{Fe}$, $\mathrm{Ca}$, Ti and K (A.R Mermut and A.F. Cano, 2001). The content of these elements are more or less similar. It is also found that other elements such as $\mathrm{P}, \mathrm{Sr}, \mathrm{Zn}, \mathrm{Mn}, \mathrm{V}, \mathrm{Y}, \mathrm{Zn}, \mathrm{Cu}$, $\mathrm{Rb}, \mathrm{Ga}$ and $\mathrm{As}$ in the sample but the concentration is less $0.5 \%$. Due to the low content of calcium compound which is less than 3\% makes the sample potential for ceramic production (Ben Zaied et all, 2015).

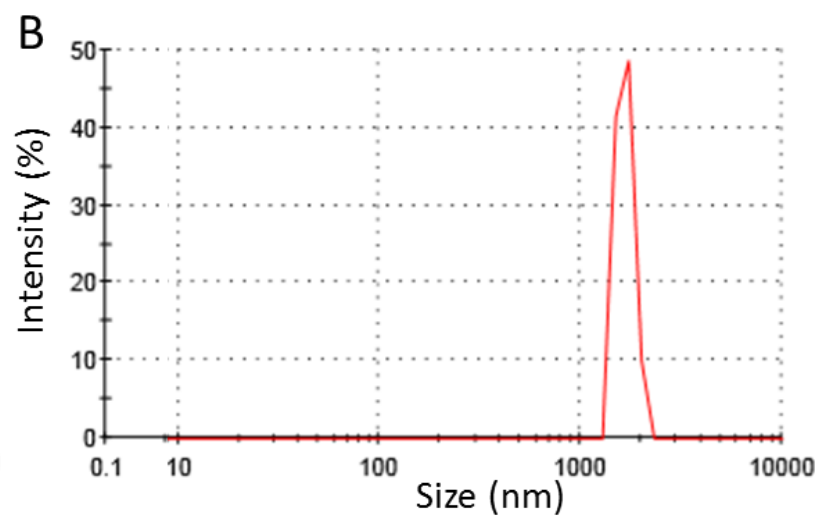

(A) lowland and (B) Agamplateu area

further treatment can be performed such as ultrasonication and alkaline-aging treatment to reduce the particle size obtained.

\section{CONCLUTION}

The analysis of mineral content of soil obtains from highland and lowland has been demonstrated. It was found that the highland soil is characterize by illite, kaolinite, illitesmectite and $\mathrm{SiO}_{2}$ (quartz) whereas in lowland also contains same minerals but with the absence of illite. Nevertheless new mineral 
namely mikasite was found. This is due to the nature of temperature and depth profile of the soil source. Both soil shows low $\mathrm{Ca}$ content. Thus they are potential for ceramic production.

\section{ACKNOWLEDGMENT}

The author would like to thanks the DIPA Yayasan PGRI Padang for supporting this project under No DIPA 053/STKIPUP3M/PGRI-SB/2014.

\section{REFERENCES}

A.R Mermut and A.F. Cano. 2001. Baseline Studies of the Clay Minerals Society Source Clay: Chemical Analysis of Major Elements. Clays and Clay Minerals. (49), pp.381-386.

C.D Bain and P. H Nadeau. 1986. Composition of Some Smectites and DiageneticIllitic Clays and Implications for Their Origin. Clays and Clay Minerals. (34) pp. $455-464$

D. Robinson. 1987. Wright Ordered IlliteSmectite and Kaolinite-Smectite: Pedogenic Mineral in a Low Carboniferous Paleosol Sequence, South Wales. Clay Minerals. 22. pp. 109-118.

F. H Ben Zaied, R. Abidi, N. S. Shimiand A. K. Somarin. 2015. Potentiality of clay raw materials from Gram area (Northern Tunisia) in the ceramic industry. Applied Clay Science (112), pp. 1-9

H. K Herbert, J. Kasbohm, L.N Thanh, L. Meyer, T. Hoang-Minh, M. Xie, R. F. Mählmann. 2016. Alteration of expandable clays by reaction with iron while being percolated by high brine solutions. Applied Clay Science. 121122.pp.174-187

I. Z. Mukasa-Tebandeke, P. J. M. Ssebuwufu, S. A. Nyanzi, A. Schumann, G. W. A. Nyakairu, M. Ntale, F. Lugolobi. 2015. The Elemental, Mineralogical, IR, DTA and XRD Analyses Characterized Clays and Clay Minerals of Central and Eastern Uganda. Advances in Materials Physics and Chemistry. pp. 67-86

J. C. Austin, A. Perry, D. D. Richter, P. A. Schroeder. 2017. Modifications of 2:1
Clay Minerals In A KaoliniteDominated Ultisol Under Changing Land-Use Regimes. Clays and Clay Minerals. 66 (1).pp : 61-73.

J. Madejova. 2003. FTIR Techniques in Clay Mineral Studies. Vibrational Spectroscopy. 31.pp. 1-10

M. E. Haque, M. Nairuzzaman and M. H. Imam. 2013. X-Ray Diffraction Studies of Some Madhupur Clay Samples of Savar and Dhaka of Bangladesh with Especial Emphasis on Clay Minerals, International Journal of Scientific \& Technology Research. 2 pp. 174-180

M.I Carretero, M. Dondi, B. Fabbriand Raimondo, M. 2002. The Influence of Shaping and Firing Technology on Ceramic Properties of Calcareous and non-Calcareous Illitic- Chloritic Clays. Appl. Clay Sci. 20 pp. 301-306.

M.S. Hossain. 1997. Clay Mineralogy of Mottled Soils from the Level Barind Tract and its Geomorphic Implications in Relation to Deep Brown/Red Soils of the Madhupur Tract, Bangladesh. Journal of Geology. (16) pp. 43-53

R. M. Hazen, D. A. Sverjensky, D. Azzolini, D. L. Bish, S. C. Elmore, L. Hinnov and R. E. Milliken. 2013. Clay Mineral Evolution, American Mineralogist 98 pp. 2007-2029.

R. S. Kumar and P. Rajkumar. 2014. Characterization of Minerals in Air Dust Particles in the State of Tamilnadu, India Through FTIR, XRD and SEM Analyses. Infrared Physics \& Technology (67), pp. 30-41

S. Ahmad, H. Zaini, A. B. Zaharidah. 2009. XRF Determination of Major Elemental Contents of Clay Samples from NorthWest Peninsular Malaysia. Journal of Nuclear and Related Technologies. 6 pp. 230

S. Battaglia, F. Gherardi, G. Gianelli, L. Leoni and F. Origlia. Clay Mineral Reactions in an Active Geothermal Area (Mt. Amiata, Southern Tuscany, Italy), Clay Minerals 42 (2007) 353-372. 